\title{
Perceptions of risk factors associated with coronary disease
}

\author{
Percepções dos fatores de risco associados à doença coronariana \\ Percepciones de factores de riesgo asociados con enfermedad coronaria
}

Received: 07/17/2021 | Reviewed: 07/21/2021 | Accept: 07/22/2021 | Published: 01/01/2022

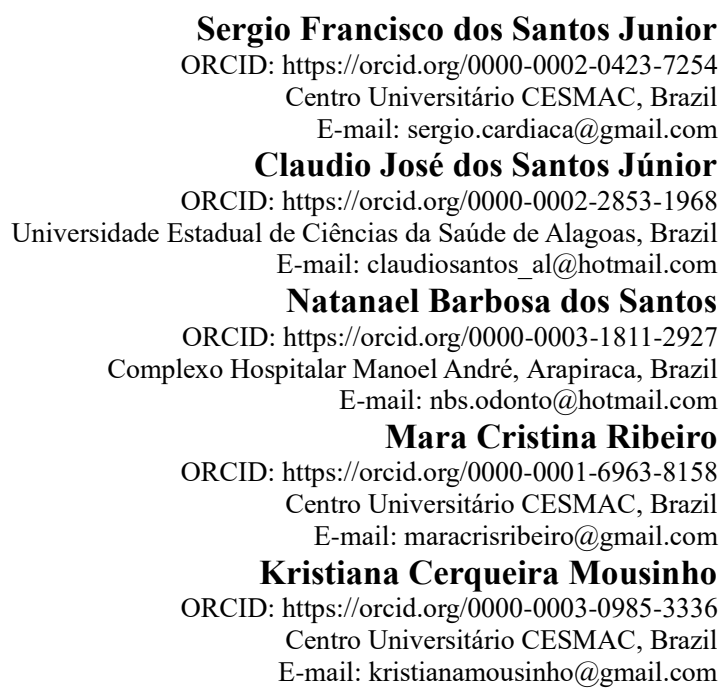

\begin{abstract}
This study aimed to analyze the perception of patients and the prevalence of systemic and oral risk factors in patients with coronary artery disease (CAD). This is a quali-quantitative study in which 56 patients with CAD had quantitative and qualitative data collected and analyzed. Of the 56 patients who made up the sample, 41 had their oral cavity examined and 11 were interviewed. Of this total, $46.42 \%$ have no education; $64.28 \%$ are unemployed; $72.41 \%$ have low family income; $25 \%$ are smokers; 17.85 are obese; $76.78 \%$ have hypertension; $30.36 \%$ diabetes; and $64.29 \%$ admitted having inadequate eating habits. In the qualitative analysis, 4 (four) categories emerged from the interviews and it was possible to identify, in general, the lack of knowledge of risk factors regardless of education level. In general, it was observed that, in this study, the social and demographic conditions and morbidity rates of the studied population were worse than the average of data from regional and national registries. The perception of risk factors as a cause of CAD was low and regardless of education level. The population studied showed a higher prevalence of risk factors when compared to regional and national averages. These facts may have increased the subjects' vulnerability and contributed to the development of CAD.
\end{abstract}

Keywords: Cardiovascular diseases; Risk factors for heart disease; Qualitative research.

\section{Resumo}

Esse trabalho teve como objetivo analisar a percepção dos pacientes e a prevalência de fatores de risco sistêmicos e orais em pacientes com doença arterial coronariana (DAC). Trata-se de estudo quali-quantitativo em que 56 pacientes com DAC tiveram dados quantitativos e qualitativos coletados e analisados. Dos 56 pacientes que compuseram a amostra, 41 tiveram a cavidade oral examinada e 11 foram entrevistados. Desse total, $46.42 \%$ não tem instrução; $64,28 \%$ são desempregados; $72,41 \%$ possuem baixa renda familiar; $25 \%$ são fumantes; 17,85 são obesos; $76,78 \%$ tem hipertensão; 30,36\% diabetes; e 64,29\% admitiram ter hábitos alimentares inadequados. Na análise qualitativa, 4 (quatro) categorias emergiram das entrevistas e foi possível identificar, de um modo geral, o desconhecimento dos fatores de risco independentemente do nível de escolaridade. Observou-se que, neste trabalho, as condições sociais e demográficas e as taxas de morbidades da população estudada foram piores do que a média dos dados de registros regionais e nacionais. A percepção dos fatores de risco como causa da DAC foi baixa e independente da escolaridade. A população estudada apresentou maior prevalência de fatores de risco quando confrontadas as médias regionais e nacionais. Esses fatos podem ter aumentado a vulnerabilidade dos sujeitos e contribuído para o desenvolvimento da DAC.

Palavras-chave: Doenças cardiovasculares; Fatores de risco de doenças cardíacas; Pesquisa qualitativa. 


\section{Resumen}

Este estudio tuvo como objetivo analizar la percepción de los pacientes y la prevalencia de factores de riesgo sistémicos y orales en pacientes con enfermedad arterial coronaria (EAC). Se trata de un estudio cuali-cuantitativo en el que se recopilaron y analizaron datos cuantitativos y cualitativos de 56 pacientes con EAC. De los 56 pacientes que componían la muestra, a 41 se les examinó la cavidad bucal y se entrevistó a 11. De este total, el 46,42\% no tiene educación; 64,28\% están desempleados; El 72,41\% tiene ingresos familiares bajos; El 25\% son fumadores; 17,85 son obesos; 76,78\% tiene hipertensión; 30,36\% de diabetes; y el 64,29\% admitió tener hábitos alimentarios inadecuados. En el análisis cualitativo surgieron 4 (cuatro) categorías de las entrevistas y se pudo identificar, en general, el desconocimiento de los factores de riesgo independientemente del nivel educativo. En general, se observó que, en este estudio, las condiciones sociodemográficas y las tasas de morbilidad de la población estudiada fueron peores que el promedio de los datos de los registros regionales y nacionales. La percepción de los factores de riesgo como causa de EAC fue baja e independientemente del nivel educativo. La población estudiada mostró una mayor prevalencia de factores de riesgo en comparación con los promedios regionales y nacionales. Estos hechos pueden haber aumentado la vulnerabilidad de los sujetos y contribuido al desarrollo de CAD.

Palabras clave: Enfermedades cardiovasculares; Factores de riesgo de enfermedad cardíaca; Investigación cualitativa.

\section{Introduction}

Cardiovascular Diseases (CVD) are of concern worldwide, both in developed and developing countries (Cesse et al., 2009; Brasil, 2011; Brasil, 2012). A recent study conducted in 195 countries showed that chronic noncommunicable diseases such as cardiovascular diseases are the leading cause of death worldwide; In 2016, 17.6 million people died due to these types of diseases, including Coronary Artery Disease (CAD) and stroke (Naghavi et al., 2017).

Cardiovascular diseases are of great importance at health care in Brazil and is the main cause of death in all regions. According to data from the Brazilian Institute of Geography and Statistics (IBGE), until the age of 40, deaths from cardiovascular causes are only lower than violent causes (homicides and traffic accidents), and from the age of 40, CVD are the main cause of death in the national territory (Brasil, 2011; Brasil, 2012).

Coronary Artery Disease and Cerebral Vascular Accident were responsible for more than $85 \%$ of all deaths from Cardiovascular Diseases in 2016 and the number of deaths by Coronary Artery Disease increased $19 \%$ in 10 years worldwide from 7.96 million in 2006 to 9.48 million in 2016 (Naghavi et al., 2017).

Epidemiological data from the Ministry of Health show that between January 2008 and April 2018 there were 907,181 deaths from CVD in Brazil, mainly in Southeast (431,173) and Northeast $(210,202)$ regions of the country. 192,371 of these patients died due to coronary disease and 218,633 for stroke (Brasil, 2018a).

In the same period, 11,704,445 people were hospitalized due to CD throughout Brazil, of which, 139,321 in the State of Alagoas: 103,601 in the first macro-region of health and 35,720 in the second macro-region (Brasil, 2018b).

Between 2008 and 2018, Brazil had a 7.75\% mortality rate due to CVD on the Northeastern region was 8.08\%. On the State of Alagoas $10.98 \%$ and on the second macro-region of health of the State it was $14.19 \%$.

The development of CVD can be anticipated or even caused by diseases and associated conditions that constitute risk factors for that development. There are non-modifiable risk factors such as age, sex, genetic inheritance, and modifiable factors such as smoking, inappropriate diet, obesity, hypertension, dyslipidemia, diabetes, metabolic syndrome, lack of physical activity, psychosocial factors and periodontitis.

A study published in 2015, points out that there is an association between the presence of periodontal disease and future onset of myocardial infarction, but with an undetermined causal relationship, while others show that correct dental prophylaxis may reduce the risk of acute myocardial infarction (Lee et al., 2015; Xu et al., 2017).

It is known that in Brazil, since 2012, the main causes of death due to CVD are Coronary Artery Disease (CAD) and stroke, and CAD has higher rates than stroke in both genders. In the most recent government research on the epidemiology of CVD in Brazil, hypertension was the most prevalent factor, with $21.4 \%$ of the population over 18 years old, in which only $80 \%$ 
used appropriate medications. $12 \%$ were diabetics, only $80 \%$ with medications, $14.5 \%$ had dyslipidemia, $18.9 \%$ of men were active smokers as so as $11 \%$ of women. It was also noticed that the mortality due to CVD among blacks was higher than in other races in Brazil (Lotufo; Lotufo, 2015).

The World Heart Federation has an agenda for sustainable development in the world until 2030, which includes improvements in various social and health indicators such as the abolition of poverty, hunger, the promotion of justice and peace. Good health is one of the main goals and they have, as one of its main points, the reduction of one third of premature deaths due to non-compulsory notification diseases through prevention and treatment actions (Markbreiter, 2016).

Chronic diseases of Non-compulsory notification, mainly cardiovascular, cancer, chronic respiratory diseases and diabetes are the leading cause of death in the world (60\% of the total), in wich $30 \%$ caused by CVD, but surprisingly neglected in the global health agenda despite having a profound economic and social impact. If the global goal of mortality reduction were achieved by 2015, 36 million lives could be spared, according to the study. The major challenge is to show that these goals can be achieved cost-effectively with existing strategies (Beaglehole et al., 2007).

The values of the cost of the Brazilian social security system are extremely high. Data obtained in the Social Security system shows that, between 2004 and 2016, public financial assistance due to cardiovascular diseases were U\$ 1.416.640.307,06 (one trillion, four hundred and sixteen billion, six hundred and forty million, three hundred and seven thousand dollars and six cents) (Brasil (2016).

Coronary Artery Disease incidence has increased by 16.6 percent between 2005 and 2015 worldwide, the equivalent of 9 million according to study which analyzed reporting data from 195 countries between 1980 and 2015(Brasil (2016).

Much is known about the most common causes of mortality due to chronic diseases in Brazil and in the world, and although there are many studies on the risk factors of cardiovascular diseases, the second macro-region of health of Alagoas has mortality rates higher than national and regional average. To minimize this situation with strategies that contribute to the improvement of these rates is it necessary to understand the reasons why numbers of CAD cases is still high among studied population.

Understanding the patients' perception of the risk factors that may have contributed to the onset of the coronary disease is something that has not been found in publications until now, therefore, analyzing the presence of these factors and understanding them under the patients' own perception is an important way to collaborate with the increase of knowledge in the scientific perspective so that patients, health professionals and government departments may have more subsidies in improving health care and creating strategies for reduction of morbidity and mortality rates.

That given, the aim of this research is to analyze the patients' perception and prevalence of systemic and oral risk factors in patients with Coronary Artery Disease.

\section{Methodology}

This study employed a quali-quantitative design, with observational, descriptive, cross-sectional research (Marconi \& Lakatos, 2003) in which patients over 18 years old of both genders with coronary artery disease confirmed by coronary angiography had quantitative data collected by forms and were distributed in four groups according to level of education. Sample took place in Arapiraca city, State of Alagoas, Northeast Brazil.

Ethical approval was obtained from the Local Research Ethics Committee (Code number 2.645.099) and individual form consent was fulfilled by each participant. Researchers assured confidentiality, anonymity and preserved the participants' right to withdraw at any time during the study. 
For quantitative analysis, social and demographic data was tabulated in Excel® spreadsheet and the descriptive analysis was presented in frequency tables. The same was made for the data obtained from the categorization from the oral dental examination.

Qualitative information was obtained from individual semi-structured interviews conducted at the cardiology center of the hospital where they attended to consultations. Interviews were conducted with audio recordings and with use of a guiding script with open answer questions as follows:

1. In your opinion, what were the reasons that led you to develop this disease?

2. In your opinion, which of these risk factors may cause this type of illness that you have? (presentation of figures showing bad habits or risk factors).

3. Do you think that people know that these risk factors may cause heart disease?

4. In your opinion, what could be done from now on in order to people do not develop this kind of disease?

5. Would you like to say something on this subject that I did not ask you?

Interviews were verbatim transcribed, categories were formed from the narratives and themes emerged as recommends content analysis technique under Bardin's perspective (Bardin, 2011).

\section{Results and Discussion}

56 patients were sampled, 41 of them had the oral cavity examined and 11 were interviewed for further qualitative data elaboration. Table 1 shows social and demographic data of patients in which most of them were men (62.5\%), 50 to 60 years old $(48.21 \%), 100 \%$ Brazilians and most of them claimed to be brown race (37.5\%).

Regarding scholar level of education, $46.42 \%$ comprised the uninstructed group (non-alphabetized), complete data shown in table 2. 64.28\% were non employed and with low family income, with earnings between 129,06 and 386.42 US dollars per month $(71.42 \%)$ and $46.42 \%$ declared to have personal computer and $55.35 \%$ smartphone, both with internet connection.

The obtained data regarding instruction levels evidences a high disadvantage of the individuals in relation to the national and regional average. According to the PNAD of 2017, 7.2\% of Brazilians above 25 years do not have an adequate instruction and an average of the same group in the studied geographic region is $14.9 \%$. In the present study, $46.42 \%$ were classified as uninstructed (IBGE, 2018).

Most patients did not engage in formal jobs (64.28\%) and had low family income, which represents a lower economic condition in the studied region (IBGE, 2018).

Regarding the risk factors (Table 2), it was observed that $25 \%$ of the volunteers were smokers, number which exceeds the average of the northeastern region of Brazil, of $17.6 \%$ (IBGE, 2008). In a study conducted by Sverre et al. (2017) with 1083 patients with obstructive coronary disease in Norway, 36\% of the patients were smokers at diagnosis (Sverre et al., 2017). The same characteristics were identified in a large ecological study in Scotland, where $20.6 \%$ of the population with a diagnosis of CAD was smoker and 44.2\%, former smokers (Blane et al., 2017).

The present study revealed that a considerable part of the sample (30.36\%) are diabetic and $64.29 \%$ of respondents admitted having poor eating habits, characterized by high consumption of fats and sugars and low fiber intake (Group TAC, 2008). 
Table 1 - Economic, social, demographic and epidemiological profile.

\begin{tabular}{|c|c|c|}
\hline & $\mathbf{N}$ & $\%$ \\
\hline $\begin{array}{l}\text { Are you employed? } \\
\text { No } \\
\text { Yes } \\
\text { I do not want to answer }\end{array}$ & $\begin{array}{l}36 \\
19 \\
01 \\
\end{array}$ & $\begin{array}{r}64,28 \% \\
33,92 \% \\
1,78 \% \\
\end{array}$ \\
\hline $\begin{array}{l}\text { Qual a renda familiar (U\$) } \\
\text { Until } 64,40 \\
64,40 \text { to } 128,81 \\
129,06 \text { to } 386,42 \\
\text { Above } 386,67 \\
\text { I do not want to answer }\end{array}$ & $\begin{array}{l}02 \\
02 \\
40 \\
07 \\
06\end{array}$ & $\begin{array}{r}3,57 \% \\
3,57 \% \\
71,42 \% \\
12,50 \% \\
10,71 \%\end{array}$ \\
\hline $\begin{array}{l}\text { Gender } \\
\text { Male } \\
\text { Female } \\
\text { I do not want to answer }\end{array}$ & $\begin{array}{l}35 \\
21 \\
00 \\
\end{array}$ & $\begin{array}{r}62,50 \% \\
37,50 \% \\
0,00 \%\end{array}$ \\
\hline $\begin{array}{l}\text { Age group (years) } \\
30 \text { a } 40 \\
40 \text { a } 50 \\
50 \text { a } 60 \\
60 \text { a } 70 \\
\text { Over } 70\end{array}$ & $\begin{array}{l}01 \\
06 \\
27 \\
16 \\
06\end{array}$ & $\begin{array}{l}01,78 \% \\
10,70 \% \\
48,21 \% \\
28,57 \% \\
10,71 \%\end{array}$ \\
\hline $\begin{array}{l}\text { Color (Race) } \\
\text { White } \\
\text { Black } \\
\text { Brown } \\
\text { Indian } \\
\text { I do not want to answer }\end{array}$ & $\begin{array}{l}20 \\
13 \\
21 \\
00 \\
02\end{array}$ & $\begin{array}{l}35,71 \% \\
23,21 \% \\
37,50 \% \\
00,00 \% \\
03,57 \% \\
\end{array}$ \\
\hline $\begin{array}{l}\text { Nationality } \\
\text { Brazilian } \\
\text { I do not want to answer } \\
\end{array}$ & $\begin{array}{l}56 \\
00 \\
\end{array}$ & $\begin{array}{r}100 \% \\
0,00 \% \\
\end{array}$ \\
\hline $\begin{array}{l}\text { Level of education } \\
\text { Uninstructed (i.e. non alphabetized) } \\
\text { Primary education } \\
\text { High school } \\
\text { Higher education }\end{array}$ & $\begin{array}{l}26 \\
18 \\
08 \\
03\end{array}$ & $\begin{array}{r}46,42 \% \\
32,14 \% \\
14,28 \% \\
5,35 \% \\
\end{array}$ \\
\hline $\begin{array}{l}\text { Home computer with internet access } \\
\text { No } \\
\text { Yes } \\
\text { I do not want to answer }\end{array}$ & $\begin{array}{l}29 \\
26 \\
00\end{array}$ & $\begin{array}{r}51,78 \% \\
46,42 \% \\
1,78 \%\end{array}$ \\
\hline $\begin{array}{l}\text { Smartphone with internet access } \\
\text { No } \\
\text { Yes } \\
\text { I do not want to answer }\end{array}$ & $\begin{array}{l}24 \\
31 \\
01\end{array}$ & $\begin{array}{r}42,85 \% \\
55,35 \% \\
1,78 \%\end{array}$ \\
\hline
\end{tabular}

Source: Research Collection (2021).

The present study revealed that A considerable part of the sample $(30.36 \%)$ are diabetic and that a percentage of $64.29 \%$ of respondents admitted having poor eating habits, characterized by high consumption of fats and sugars and low fiber intake. 
Table 2 - Risk factors for coronary artery disease.

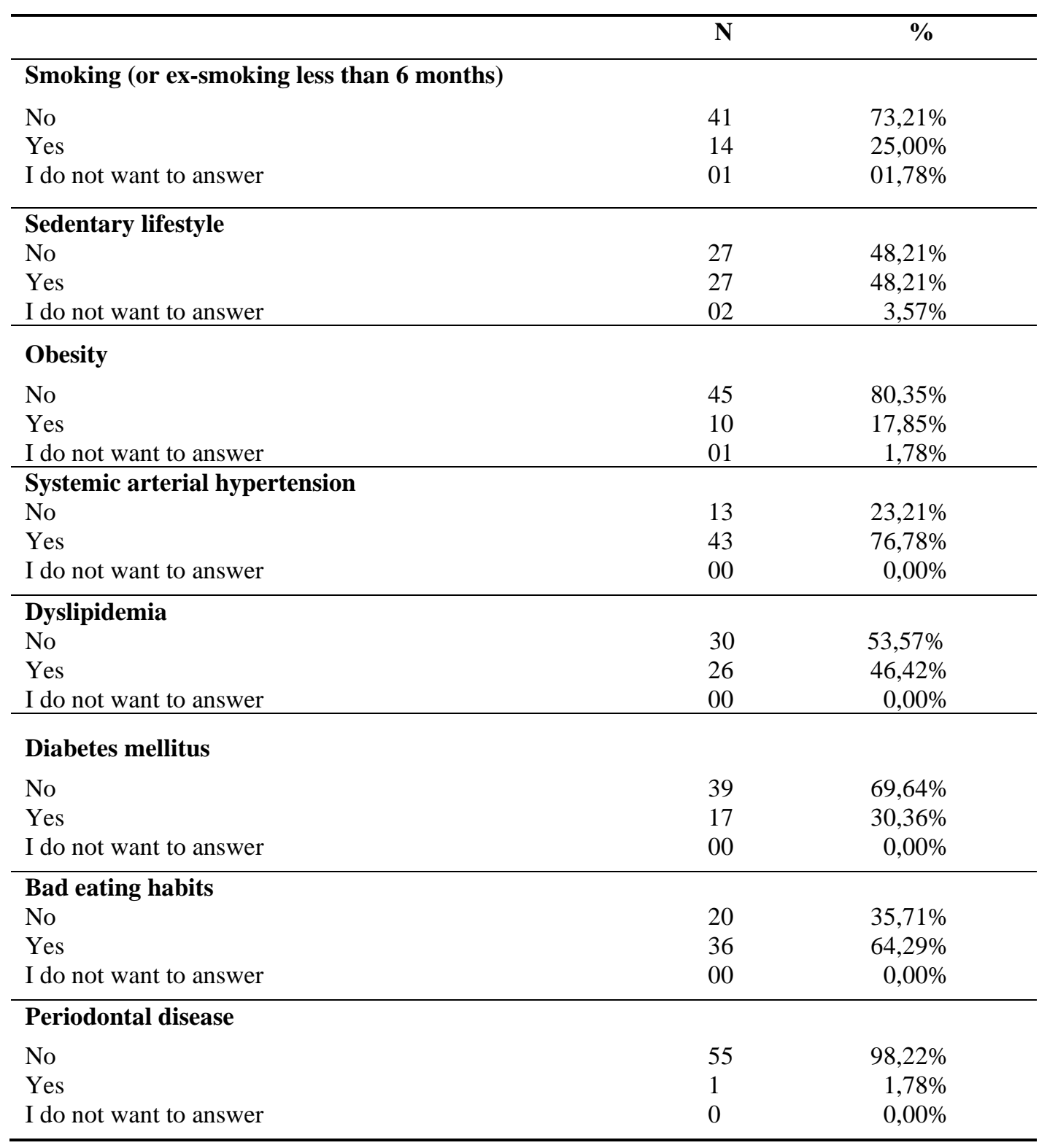

Source: Research Collection (2021).

The following categories emerged from the interviews carried out with the 11 selected patients: patients' perception of the reasons for the development of the disease they have. Patients' perceptions about which factors may cause the kind of disease they have, perceptions of the patients about general knowledge of people regarding risk factors' potential of causing heart disease, patients' opinions on what could be done in order to people do not develop this type of disease and free opinions on topics explored or not.

\section{Patients' perception of the reasons for the development of the disease they have}

When patients were asked about the possible reasons for developing their heart disease, it was possible to perceive a wide range of possible causes they perceived, most related to modifiable lifestyle habits such as smoking. In the group of patients without education (uninstructed) there were found a lot of causes related to environmental factors, as seen in the speech of "A": "... I think that it was because stress, pollution, right? Forced labor...", but also the total lack of perception was 
identified, denoting the individual's vulnerability in the "C" response: “... I do not understand what caused it, except that I was in a good mood and then I felt... I got hoarse and felt that strong pain in my chest... "

In the different positions related to the causes of the disease, coupled with the differences related to educational level, corroborate with other Brazilian and international studies that have indicated the prevalence of noncommunicable chronic diseases, such as heart disease, in the segments of the population (Barreto \& Figueiredo, 2009; Dalstra et al., 2005; Barros et al., 2011).

It was also possible to identify a relatively common profile of fatalism, as seen in the speech of "J": "... doctor, it is difficult to correctly say this answer, because it happened naturally ... with me. Well, I guess it must have been... I guess... it's... depending on the age, right?".

\section{Patients' perceptions about which risk factors may cause the type of disease they have}

The totality of the interviewees attributed risk to smoking and poor eating habits (sugars, excess fat and low fiber intake), as seen in the statements of "E", patient with a primary education: "Smoking, right? I never smoked, but I think that's the worst thing" and "I do not reject food at all, nothing. I think I got sick due to this ... greasy food, fried, fat? I think it causes".

The quantitative data from the survey showed that $25 \%$ of the patients were smokers, more than the average of the northeast region of $17.6 \%$ (16) and that $64.29 \%$ maintained unhealthy eating habits before the onset of coronary disease.

It is worth mentioning that three of the 4 patients with high school and above (higher level) did not recognize diabetes as a precipitating factor of coronary disease, even if stimulated by the visual information of the risk factors presented. According to Wild et al. (2004), diabetes increases 2 to 3 times the risk of developing CVD, including CD.

Survey data showed that $48.41 \%$ were sedentary, but only half of the interviewees considered this a risk factor and only one third of uninstructed patients considered arterial hypertension as a risk factor, while in the group with primary education this rate rose to two thirds and in the groups with high school and higher $100 \%$ of the patients considered hypertension as a potential cause of the coronary artery disease.

Only $40 \%$ of respondents highlighted high levels of cholesterol and triglycerides as risk factors. And only a quarter of the supposedly more enlightened (with high school and higher education) also considered this and it is known that high levels of cholesterol and triglycerides are directly related to the development of atherosclerotic plaques causing coronary obstruction (Grundy et al., 2004).

Obesity was considered a risk factor by $80 \%$ of respondents, as seen in the "E" speeches ... "being fat is also not good. I think it's the cause". , From "F" "Fat ... oh, this one I think is the main thing, see?", Both with elementary education, from "H": "What can contribute to clogging? Smoking, Sedentary, also obesity..." and "J": "high blood pressure, smoking is.... sedentary lifestyle, poor diet... bad diet has to do with obesity, right? That is it..." with high school and higher education, respectively.

No patient interviewed in the groups without education and elementary education recognized sedentary lifestyle as a risk factor, while $100 \%$ of the patients in the high school and higher education groups recognized this as a risk factor.

As for periodontal disease, only $30 \%$ of the patients perceived a risk in this oral condition. However, $96.2 \%$ of the patients who had teeth in the mouth and had their oral cavity examined had signs of risk (bleeding or dental calculus) or periodontal disease (Figure 1). It should be pointed out that bleeding and dental calculus were analyzed grouped into periodontal pocket scores because they are factors indicative of the risk of periodontal disease progression. 
Figure 1 - Periodontal conditions, by severity, of patients with cardiopathy who have teeth $(\mathrm{n}=27)$.

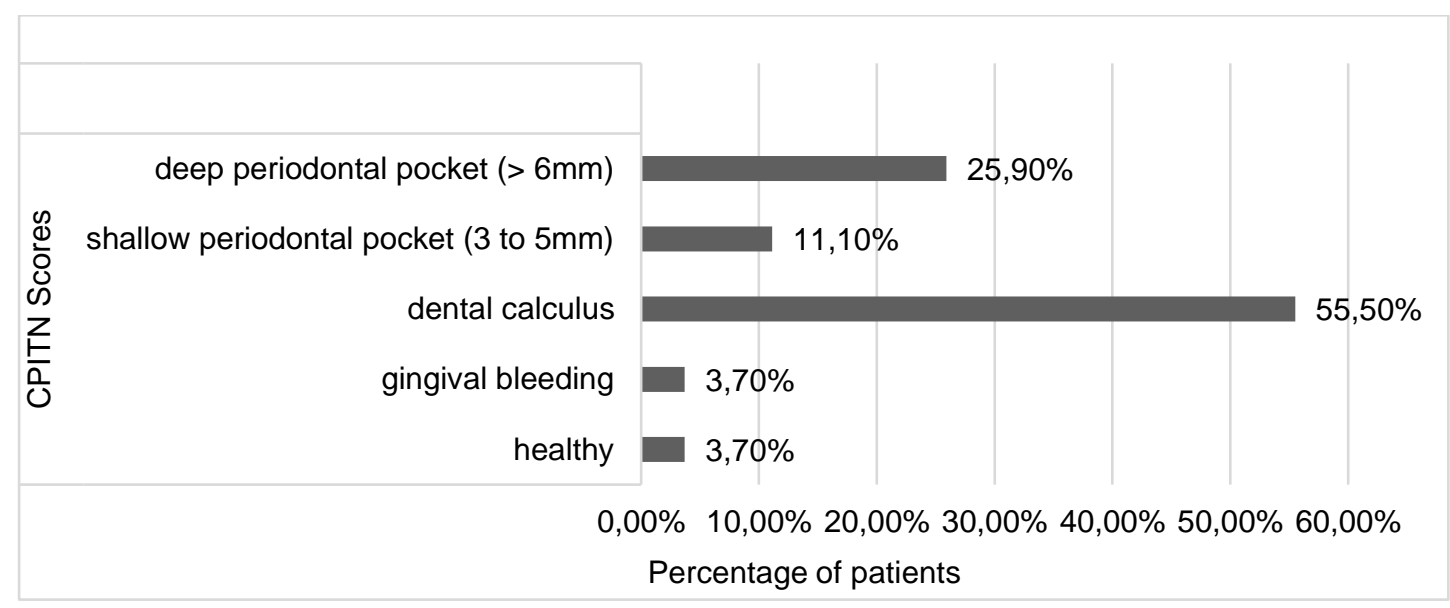

Source: Research Collection (2021)

It was evidenced that $93 \%$ of the patients, excluding the edentulous ones, do not use dental floss and $82.92 \%$ do not use mouthwash. Furthermore, only $28.57 \%$ of the patients brush their teeth three times a day.

\section{Perceptions of the patients about general knowledge of people regarding risk factors' potential of causing heart disease}

Regarding patients' perception in this theme, it was possible to show that most of them believe that the population does not have this knowledge, as seen in the speech of "B" (Uninstructed): "No, they do not know ... They think that only the cigarette does. There are people who eat fat, always smoke, my sister is always smoking and I tell her, but she does not ... "and" F "(with primary education) No ... nothing .... only those who understand, but who does not understand ... I after I fell ill I found all these causes there ... If not today would be walking around... with high blood pressure and not knowing. "

The few patients who stated that there is enough knowledge have accentuated the little importance given by the citizens themselves, as stated by "I" (with High level): "They know, but not ... Brazilian is a very relapsed people, I was seeing a survey yesterday that men go 8 times less to the doctor than women, so men with their male prejudices think that nothing ... and feeds badly, drinks, takes ... smokes, gets spoiled". And for "A" (uneducated): "we know that many things" hurt "us, but we do not care about these things ... and there is something that when we worry about it is already far too advanced... "

\section{Patients' opinions on what could be done in order to people do not develop this type of disease}

When they are encouraged to suggest how to prevent more people from developing coronary artery disease, a variety of ideas could be identified, but they converge towards the same aspect: improving information

Many patients, each in their own way, perceived themselves as a multiplier of information insofar as they use or intend to use their own cases as a lesson to others, as can be denoted in the speech of "B" (Uninstructed): "Look, there in my community black 'Ciço' stopped smoking, after me, black 'Ciço', 'Maria' quit smoking, 'Jaquele' quit smoking, 'Magda' quit smoking, about 6 people quit smoking ... After I had heart attack", also on "D" speech: (primary education):" Because she see s others talking, there she says to another: look, eat this, do not eat fatty food, do not eat salty food, do not eat like this these things of fat, have to go decreasing mass intake. Than you go and say to the other. "And" J "(with High education):" Debates... including showing, I mean, inviting people who have the problem, right? To participate in debates, of campaign, to show in the video... Testimonials, all these things". 
There were suggestions of interference from the government, as "I" said in his speech: "It would be in this aspect of making people really feel, not just to inform, but it is to make the people feel, show them the bad side... regulate the products based on fat, margarine, butter, then put on them: look, this product can cause artery clogging and everything...".

Although it is known that actions that have impacted the reduction of the risk factor for CAD have been the laws that have reduced the advertisements and restricted the forms of commercialization of cigarettes in Brazil, it should be remembered that normative and regulatory actions have limits and need to be discussed with the community (Simão et al., 2013) at risk of interfering with individual freedom of individuals.

\section{Conclusion}

The studied population has higher prevalence of risk factors' diseases than the regional and national averages. The perception of the risks brought by the diseases as risk factors for the onset of coronary artery disease is low and irrespective to the educational level. These facts seem to have increased the vulnerability of subjects to the onset of coronary artery disease, which may continue to happen at high rates if there are no specific actions to reverse this condition.

\section{References}

Bardin, L. (2011). Análise de conteúdo. 70, 229.

Barreto, S. M. \& Figueiredo, R. (2009). Doença crônica, autoavaliação de saúde e comportamento de risco: diferença de gênero. Rev Saude Publica, 43(Supl 2), 38-47.

Barros, M. B. et al. (2011). Tendências das desigualdades sociais e demográficas na prevalência de doenças crônicas no Brasil, PNAD: 2003- 2008. Ciênc saúde coletiva, 16, 3755-68.

Beaglehole, R., Ebrahim, S., Reddy, S. et al. (2007). Prevention of chronic diseases: a call to action. Lancet, 370, 2152-7

Blane, D. N., Mackay, D., Guthrie, B. et al. (2017). Smoking cessation interventions for patients with coronary heart disease and comorbidities. Br J Gen, 67(655), e118-e129.

Brasil (2011). Plano Nacional de Saúde 2012-2015.

Brasil (2012). Saúde Brasil 2011 - Uma análise da situação de saúde e a vigilância da saúde da mulher. Ministério da Saúde.

Brasil (2016). Anuário Estatístico da Previdência Social. Base de dados históricos da Previdência Social.

Brasil (2018). Sistema de Informações Hospitalares do SUS (SIH/SUS) - Sistema de Informações de Mortalidade (SIM/SUS).

Brasil (2018). Sistema de Informações Hospitalares do SUS. Departamento de informática do SUS. SIHSUS - DATASUS.

Cesse, E. Â. P., Carvalho, E. F., Souza, W. V. et al. (2009). Tendência da mortalidade por doenças do aparelho circulatório no Brasil: 1950 a 2000 . Arq Bras Cardiol, 93(5), 490-7.

Dalstra, J., Kunst A., Borrell C. et al. (2005). Socioeconomic differences in the prevalence of common chronic diseases: an overview of eight European countries. Int J Epidemiol., 32(2), 316-26.

Group TAC (2008). Intensive Blood Glucose Control and Vascular Outcomes in Patients with Type 2 Diabetes. N Engl J Med, 358(24), 2560-72.

Grundy, S., Cleeman, J., Merz, C. et al. (2004). Implications of recent clinical trials for the National Cholesterol Education Program Adult Treatment Panel III guidelines. Circulation, 227-239.

IBGE (2008). PNAD Contínua 2008. In: Pesquisa Nacional por amostra de domicílios contínua. IBGE.

IBGE (2018). PNAD Contínua 2017. In: Pesquisa Nacional por amostra de domicílios contínua. IBGE.

Lee, Y. L., Hu, H. Y., Chou, P. et al. (2015). Dental prophylaxis decreases the risk of acute myocardial infarction: a nationwide population-based study in Taiwan. Clin Interv Aging, 10, 175-82.

Lotufo, P. A., Lotufo, P. A. (2015). Non-communicable diseases in Brazil: a flood of data is coming! Sao Paulo Med J., 133(4), 283-5.

Marconi, M. D. A., \& Lakatos, E. M. (2003). Fundamentos de metodologia científica. (5a ed.), Atlas.

Markbreiter, J. (2016). CVD Advocacy Toolkit The Road to 2018. World Heart Federation. 
Research, Society and Development, v. 11, n. 1, e0211118339, 2022

(CC BY 4.0) | ISSN 2525-3409 | DOI: http://dx.doi.org/10.33448/rsd-v11i1.18339

Naghavi, M., Abajobir, A. A., Abbafati, C. et al. (2017). Global, regional, and national age-sex specifc mortality for 264 causes of death, 1980-2016: A systematic analysis for the Global Burden of Disease Study 2016. Lancet, 390(10100), 1151-210.

Simão, A., Precoma, D., Andrade, J. et al. (2013). Diretriz Brasileira de Prevenção Cardiovascular. Arq Bras Cardiol, 101(6), 1-63.

Sverre, E., Peersen, K., Husebye, E. et al. (2017). Fatores médicos e sociodemográficos predizem tabagismo persistente após eventos coronarianos. BMC Cardiovasc Disord, 17, 241.

Wang, H., Naghavi, M., Allen, C. et al. (2016) Global, regional, and national life expectancy, all-cause mortality, and cause-specific mortality for 249 causes of death, 1980-2015: a systematic analysis for the Global Burden of Disease Study 2015. Lancet, 388(10053), 1459-544.

Wild, S., Roglic, G., Green, A. et al. (2004). Global prevalence of diabetes: estimates for the year 2000 and projections for 2030. Diabetes Care, 27(5), 104753 .

Xu, S., Song, M, Xiong et al. (2017). The association between periodontal disease and the risk of myocardial infarction: A pooled analysis of observational studies. BMC Cardiovasc Disord, 17(1), 1-11. 